\title{
Optimizing the Millennial Role in Communities with Islamic Leadership Training
}

\author{
Muhammad Rizqi Hidayat ${ }^{1}$, Tulaihah Ning Safitri ${ }^{2}$ \\ ${ }^{1}$ Student of Postgraduate Program, Yogyakarta State University \\ ${ }^{2}$ Lecturer of Department of Islamic Education, Nahdhatul 'Ulama University of Indonesia \\ ${ }^{1}$ rizqimuhamad50@gmail.com, ${ }^{2}$ tulaihahning.safitri@yahoo.co.id
}

\section{Keyword:}

Leadership;

Character;

Role;

Youth.

\section{ABSTRAK}

The millennial role in society as an agent of change towards the character of the present age youth who are indifferent to their surroundings as expected by the form of optimizing Islamic youth leadership in their environment. This study discusses how important the character of Islamic leadership in the millennium is now. The study population was youth cadets Sidoarum village in Yogyakarta. The purpose of this study was to determine the effect of Islamic leadership training on a millennial character to play a role in society. This type of research is qualitative descriptive with the "Rapid Rural Appraisal" approach. Data collection came from 28 respondents through observation, questionnaire and documentation methods. Data analysis techniques with data reduction, data presentation, and concluding. The results of this study indicate that: Islamic leadership training has a significant influence of $83 \%$ from the previous $67 \%$ of Millennial characters to optimize roles in society.

\begin{tabular}{|c|c|c|}
\hline 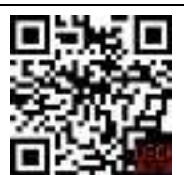 & $\begin{array}{l}\text { Article History: } \\
\text { Received: 07-02-2019 } \\
\text { Revised : 26-03-2019 } \\
\text { Accepted: } 27-04-2019 \\
\text { Online : } 30-04-2019\end{array}$ & $\begin{array}{l}\text { This is an open access article under the CC-BY-SA license } \\
\text { https://doi.org/10.31764/iieca.v2il .780 }\end{array}$ \\
\hline
\end{tabular}

\section{A. INTRODUCTION}

Today, Indonesian youth have lost much of their identity, especially in terms of nationalism and patriotism. Therefore we need thinking and rediscovery in the development of national character. In 1998 Indonesian youth made a reform movement towards the new government, but up to ten years of the order of reform, it still had not succeeded out of the crisis. Unemployment is rampant, and there is a threat of disintegration of the nation, widespread corruption, and the moral of the nation that is destroyed. The Indonesian youth development strategy can be done by (1) building moral and noble and holy character, (2) building nonphysical -physical by prioritizing the interests of the nation and state above personal, group or group interests, (3) building human resources with exemplary, solidarity, mutual cooperation, courtesy, courtesy, mutual respect and mutual respect, and maintaining social sensitivity, (4) build fighting spirit and love for the motherland, and (5) build future mapping as a blueprint for nation character building.

The development of Indonesia's young generation is: (a) empowering young people to raise the potential of youth to participate in development, (2) Youth development to develop managerial potential, entrepreneurship and youth pioneering, and (3) protection of youth helping youth in facing demoralization, nationalism degradation, destructive actions, regeneration and protection of the rights and obligations of youth. Finally, it is hoped that in the 
future there will be national leaders from the young generation with nationalism and love for the country, namely young people who have noble attitudes, intellectuality and behavior.

The term youth is no stranger to our ears. Everyone must understand what youth is and who is a young man. Since October 28, 1928, as an event where the youth was declared with the term "youth oath." This term certainly motivates young people from Sabang to Merauke to move that the nation's future is in the hands of the youth. The proclamation once made a speech that "give me ten young men, surely I shake this earth ...". That's one of the quotes of his fiery speech at the time of the youth oath. The message from the quotation of this speech has a very special meaning, that youth is the actor of all changes of this nation. Its role is very much needed in the social transformation of our society. This means that with the presence of youth, of course, this nation will not be independent, even still colonized. Every movement is one of the elements there is a young man. Therefore it is not surprising that youth is a very thick term to explore how youth terminology. Because youth is a period where they experience a transition from children to adults. So everyone has been a part of youth. Every young man is given the right and authority to actualize all his wishes in any form for this country through any media.

Entering the ASEAN economic community (MEA) in the era of industrial revolution 4.0, at present, the term youth is now rarely echoed again, but by giving another designation with the word "millennial." This term is often used everywhere. Of course, the meaning of this term does not change just the different times that change it. This modern term does not reduce the enthusiasm and motivation of millennials in making positive activity movements such as on campus, public places, social media and so on. They use the tool as an aid to facilitate their activities such as gadgets, internet or others. Of course, here we can know whether these millennials can play many things when they are without this aid - the extent to which they can optimize all their abilities in society. The role here is to be able to provide positive innovation by the needs of the times for the community. The attitude of leadership skills has been built on them so that they can become agents of change according to the basic service to the country. It seems difficult, but if there is an intention, there must be a way to move change by optimizing the millennial role in the community by debriefing Islamic leadership. Leadership according to Islam has actually been a long term since the time of Prophet Adam 'peace be upon him was revealed on this earth as stated in the Surah Al Baqarah verse 30 which says ..... "and remember when your Lord said to the angels," I want to make the caliph on earth "........ in the Al Qur'an, the term leader is often mentioned, the term "leadership" is the verb of the word "leader". With this designation, we know that everyone is a leader, including youth, who is expected and awaited by his role in the community as an effort to manifest a change towards a better future.

Guidance of youth through Islamic leadership training to be more optimal in contributing to society is a method of self-provisioning towards an indifferent character, not feeling of being yourself, and other characteristics. In this training, the questionnaire was given in the form of a questionnaire to collect data on their characters before and after training in Islamic leadership. The goal is to find out how much impact this training has on their character so that they can play an active role in optimizing the empowerment of capabilities in the community as well as participating in any changes that occur in the community.

\section{B. LITERATURE REVIEW}

\section{Leadership in Islam}

Every human being is a leader so that every leader will be responsible for his leadership. The following statement is one of the quotes of Sahih Bukhari's Hadith Number 2368 about how the leader will be asked for the answer. The president is responsible for his leadership, the governor who is in charge of his administration, the Camat who is responsible for his leadership until the law is directed at himself how we are responsible for the leadership of ourselves in the right direction or the wrong path. In essence, humans have revealed on earth no other function as a caliph or leader on earth. Of course, this role inevitably continues to be lived as Islamic sharia which explains how important the word leader has essential values. The issue of leadership has aged as old as human history. By the principle "Primus Interpares" wherein every 
community environment, formal and non-formal organizations there is always someone who is considered "more than others," then appointed and trusted to regulate others. (Maimunah, 2017: 1).

There are at least four reasons why a leader is needed. First; naturally humans need to be regulated. Second; in some situations, a leader needs to appear to represent his group. Third; as a place to take risks when there is pressure on the group. Fourth; as a place to put power. (Veithzal Rivai, 2004: 1-2). The term leadership, in the Indonesian dictionary, comes from the word "lead" which means "guided." While the word leader itself means "the person, who leads." So leadership is the way to lead. (Debdikbud, 1994: 967). Leadership can also be interpreted as a process or ability to influence, inspire, and direct the actions of a person or group through the communication process to achieve the expected goals. As revealed by Edwin A. Fleishman; "Leadership is influencing the activities of followers through the communication process and toward the affair meant of some goals". (Edwin A. Fleishman \& James G. Hunt, 1973: 3). The success or failure of an organization or community group, whether it is a company, an educational institution, a government institution or other social organization will always be associated with the leader of the organization in question. Because of that, leadership is a crucial element in determining the effectiveness and productivity level of an organization. Harold Kontz defines leadership as influence, art or the process of influencing people so they will try to achieve group goals with willingness and enthusiasm. (Kartini Kartono, 2005: 187).

Islamic leadership training is an essential provision for millennials where they can give new colors to themselves to achieve common goals both leaders and those who are led by the agreement. Leadership looks good if those they lead have excellent and productive qualities. But the lead character does not look good, so the leader is the primary key to evaluating the error so that the quality of the lead decreases.

\section{The Role of Youth in the Community}

Role Theory describes social interactions in the terminology of actors who play according to what is defined by culture. By this theory, the hope of role is a shared understanding that guides us to behave in everyday life. According to this theory, someone who has a certain role such as a student, parent, woman, etc., is expected to have someone behave according to that role (Risnawati, 2016: 3). The role is a dynamic process of status (status). If a person carries out his rights and obligations according to his position, he carries out a role. The difference between position and part is in the interest of science. Both cannot be separated because one depends on the other and vice versa, there is no role without position or role without a role (Soerjono Soekanto and Budi Sulistyowati, 2015: 220-221). Levinson in Soekanto said the part included three things, including:

a. The role includes norms that are related to one's position or place in society. The part in this sense is a series of rules that guide a person in community life.

b. The role is a concept of what individuals can do in society as an organization.

c. The part can also be said as individual behavior that is important for the social structure of society (Soerjono Soekanto and Budi Sulistyowati, 2015: 221).

Youth is a period of the most important events in human life. This is their social period and the formation of professional guidelines, the formation of world views, the scope of values of motivation and normative (Roza A. Valeeva, Laysan A., 2014: 141). The struggle of a nation actually cannot be separated from the existence of youth. Indeed history has noted, in the development of world civilization, it has proven the role of youth as the perpetrators of the birth of a new civilization. Likewise in the development of the birth of the Indonesian nation, both beginning at the time of the struggle for independence, until the post-independence of the nation. This proves that young people can play an active role as the front guard in the process of struggle, renewal, and nation-building. Youth are young people who must be seen as "personal" who are at a certain level in the development of a person's life, with certain qualities and characteristics that are unique, with certain rights and roles and obligations with certain potentials and needs (Teddy Chandra, 2011). 
The young man is a national asset that is very expensive and priceless. The progress or destruction of the nation and state depends a lot on the young people as agents of change. In every development and change of civilization, there is always young blood who pioneered it. However, today's Indonesian youth has lost much of its identity, especially in terms of nationalism and patriotism (love of the motherland) of Indonesia. Therefore it is necessary to have re-thinking and re-inventing in nation character building (national character building) for nationally-minded youth and patriotism to rediscover national identity. (Moerdiyanto. 2011: 2). Therefore, the role of youth in people's lives is more or less the same as the role of other citizens in the community. Youth get a special place because they are considered revolutionaries who are looking for a role in the social order. In time, when they get a role, he will pour new ideas into the community. The current generation of young people is very different from the previous generation in terms of association or socialization, ways of thinking, and how to solve problems. The ancient youths were more rational and far ahead. In a sense, they are not from thinking or acting, but they formulate them carefully and review them by seeing the impacts that will emerge from various aspects.

Because the future of a nation lies in its young generation because they are the ones who replaced the previous generation in leading the nation, therefore the young generation needs to be equipped with knowledge by the guidance of the times. One way to get this knowledge can be through formal and non-formal education, both basic and higher education. Things that hinder progress must be replaced with new things by the guidance and development of the community. Therefore, in making changes, they should pay attention to their situation and conditions. (Nurul Sawitri and Bagus Kisworo, 2014). One of the young people's steps to bring this nation to a better direction is the active participation of Indonesian youth in community development efforts. Youth about community development efforts have two roles. First, youth as initiators from a group of people together with them make efforts to improve conditions in the community itself. While the second, the youth acts as a facilitator of the program that the government rolled out in terms of community development. (Wahyu Ishardino Satries, 2009).

In the process of state development, youth is a moral force, social control, and agent of renewal as an embodiment of the functions, roles, characteristics, and strategic position in national development. For this reason, the responsibility and strategic role of youth in all dimensions of development needs to be improved by the values contained in the Pancasila and the mandate of the Constitution of the Republic of Indonesia. Based on Law No. 40 of 2009 that Youth organizations are formed by youth and function to support national interests, empowering potential, and develop leadership, entrepreneurship, pioneering.

In this connection, young people have quite a lot of productive activity in their spare time. Among other things, the young people who take their studies or work outside the city have no opportunity to take part in the activities in their village, and vice versa, young people who experience early marriage, are very busy taking care of their household rather than prioritizing youth activities. The development of the community that we carry out is a series of movements for change towards progress. In some cases, the change is a very basic improvement. Changes or progress in development is not only physical changes but also bring social change. The social change contains the power of dynamics because it deals with values, attitudes, and behavior. In other words, development requires updates.

According to Islam, looking at the role of youth in society as stated in the Koran which is described through the Ashhabul Kahfi youth, namely a group of young people who have moral integrity (faith) in the Qur'an Surah Al Kahfi verse 13 Allah SWT says ... "They are young people who have faith in their God, and We also add them to guidance." (Ministry of Religion, 2010). In the hadith mentioned the sentence, Syabaabaka Qabla Haramika (Your youth before your old age). From the verses and hadith, it appears that the problem of youth by Islam is very emphasized. Emphasized because not only is youth a time of armed for old age, but also in youth that all-powerful forces are seen. Youth who are expected to have a role in society according to Islam has the following characteristics (Ministry of Religion, 2010): 
First, young people who always call upon the Alhaq (truth) in the Qur'an Surah Al-A'raf verse 181 ... "And among those whom We created there are people who give instructions with rights, and with those who have rights ( also) they carry out justice. "

Second, they love Allah and Allah loves them in the Qur'an Surah Al-Maidah verse 54 ... "0 ye who believe, whoever among you apostates from his religion, then Allah will bring a people that Allah loves them and they love Him, who are gentle towards believers, who are harsh towards those who disbelieve, who strive in the path of Allah, and who are not afraid of the reproach of those who like to reproach. That is the gift of God, He gives to whom He wills, and Allah is most extensive (His gift), and Knower. "

Third, they protect each other and remind each other and obey the religious teachings in the Qur'an Surah At-Taubah verse 71 ... "And those who believe, men and women, some of them (are) become helpers for some another. They sent (to do) the ma'ruf, prevented from the evil, established prayer, performed zakat and obeyed Allah and His Messenger. They will be given mercy by Allah; surely Allah is Mighty, Wise. "

Fourth, they are young people who fulfill their promises to Allah Subhanahu Wata'ala. Allah says in the Qur'an Surah Ar-Ra'd verse 20, "(Namely) those who fulfill God's promises and do not destroy the agreement."

Fifth, they do not hesitate in sacrificing with their souls and possessions for the benefit of Islam in the Qur'an Surah Al-Hujurat verse 15 "Surely those who believe are only believers in Allah and His Messenger then they did not hesitate, and they fought (jihad) with their wealth and soul in the way of Allah. They are the righteous people. "

Sixth, the young man (growing up) always worshiped Allah and his heart always adhered to the mosque ... The Prophet Sallallahu 'Alaihi Wassallam said, "There are seven (7) groups who will get the shade of Allah on the day there is no shade beside His shade, (namely): a fair leader, a young man (growing up) always worshiping Allah, a man whose heart adrift with a mosque, two people who love each other because of Allah, a man who always remembers Allah in everyday until the tears flow, men who are invited by a noblewoman again beautiful then he said, "I fear God who controls all nature", and men who give charity and hide (charity) charity so that his left hand is not knowing what his right hand is giving away. "(Imam Muslim, 2007: 203).

\section{Potential and Target of Indonesian Youth Development}

In addition to the problems faced by these Indonesian youth, youth also have the following potentials:

a. The number of Indonesian youth reached $37.8 \%$ of the total population, equivalent to 83.16 million people

b. The number of youth organizations in Indonesia is very much for fostering Indonesian youth leadership.

c. The potential of intellectuals (talents and interests) of Indonesian youth is adequate.

d. The motivation or enthusiasm and enthusiasm of Indonesian youth to progress is very high.

Subjects that are the targets of youth development in Indonesia include:

a. Individuals, namely the younger generation aged 18-35 years who are not yet in the container of youth groups and youth organizations.

b. The group is every young man who is in talent groups, interests, and other interests.

c. Institutions, namely every young man who is in a structural youth organization and has tiered management with orderly and orderly regulations.

\section{METHODS}

This study uses descriptive qualitative research methods. Where qualitative research is a type of research that is used to see and analyze events and social symptoms that occur more deeply (John W. Creswell, 1994). This research method is also called an artistic method because the research process is artistic (not patterned), also called the interpretive method because the research data is related to the interpretation of the data found in the field. This method is also 
often referred to as a constructive method because it can be found scattered data then the results are constructed in a theme that is more meaningful and easy to understand (Sugiono, 2016: 12).

The approach of this study is that the Rapid rural appraisal approach presents accelerated observations carried out by two or more observers or researchers, usually with different academic backgrounds. This method aims to produce qualitative observations for the needs of decision makers to determine the need for additional research in planning and carrying out activities (James Beebe, 1995, 1). The techniques for collecting data through observation, questionnaires, and documentation. Data analysis techniques by collecting data, reducing data, presenting data, drawing conclusions (M.B. Milles and M. A. Huberman, 1984). The population in this study were a youth in Sidoarum village, which numbered 28 people with details of 15 youth, and 13 young women as well as data sources for this study so that a sample of 28 respondents was obtained.

\section{RESULT AND DISCUSSION}

The results in this study indicate that 1) Islamic leadership training has a significant influence of $83 \%$ from the previous $67 \%$ of the millennial character to optimize roles in the community from 28 respondents obtained during the training. 2) During this time the youth corps work program had never held an Islamic leadership training so thanks to the impact training program the youth felt enthusiastic about participating throughout the training. 3) In the future, young people will again hold Islamic leadership training as a fortress for the millennial character now. 4) This training is very beneficial for millennials to realize that their role is very much needed in society, especially the contribution to their villages. 5) After this training, an evaluation of the next work program is needed by prioritizing village interests. 6) The community hopes that this training will give them more care and sensitivity with their villages to be able to play an active role in community activities. 7) All Stake Holder villages fully support this Islamic leadership training program so that they can foster themselves to be better prepared and able to give their best ideas to the village. Therefore, the contribution made to the village is the hope of all elements of the village to progress and develop in the future.

Youth Sidoarum village is a highly developed and developing youth organization in the last three years. The organization they established for five years ago has greatly helped the people of Sidoarum village. All aspects that they carry out start from economic empowerment, natural empowerment, and empowerment of human resources. Businesses in the form of tilapia provide an increase in their economy. The use of bamboo and rivers makes them think hard about managing to become a tourist village as well. Empowering human resources, they can optimize their role from these fields so that they can employ youth from the rural tourism sector and the economic sector through tilapia cultivation.

Organizational travel is not always easy and smooth. Where everything has a saturation point. Therefore, in the last two years, they have not contributed much to their village due to the obstacles they faced, namely first, activity. Activities for young people who are busy with their school, college and work make them forget and find it difficult to give a good role to their village. Second, the work program. Where programs designed for each deliberation are irregular, making them unable to realize what has been agreed upon. Third, Technology, the cause of this is part of the changing times with the management of technology. The difference between the youth of the past without gadgets than today's youth with gadgets makes them always want instant things. There should be a gadget that has a positive but different effect that today's youngsters are more engrossed in their gadgets than their friends. Fourth, Regeneration. The day is increasing, certainly makes the masses change. The age of youth regeneration is mostly school age from junior high school to college age.

Of course, adults who are certainly no longer taking part in the running of this organization. So that young people are now very difficult to be invited to think critically, creatively and innovatively - fifth, evaluation. Evaluation within the organization is a necessity, but if it has not been implemented at all, it is important to think that every work program implemented to 
be evaluated is a form of good and bad evaluation of what is carried out as a future reference for better: sixth, participation. Millennial roles in the community are very much awaited and anticipated. Of course, the ego attitude, indifferent and others are avoided so that every activity carried out in the community is felt sincere with a sense of belonging to the village.

Based on the results and discussion of the discussion of research on optimizing the role of millennials in the community described above, the researchers gave recommendations to youth in the village of Sidoarum. The recommendations of related researchers regarding efforts to improve the role of youth in the community after the holding of Islamic leadership training has become one of the strategies that can be done by increasing human resource development in Sidoarum village which is still interconnected with youth work programs in the village. The following is the recommendation of researchers as a step of innovation to increase the millennial role in the community after training is held, namely:

1. Organizing youth empowerment and protection institutions that are supported by professional and high integrity of human resources.

2. Making short, medium and long term work programs such as Launching programs that can protect Indonesian youth from destructive influences such as drugs, anarchism, promiscuity by making screen printing training or cultivation training, etc.

3. Upgrading work programs that have been done before

4. Organize youth resources effectively and efficiently

5. Develop a healthy and democratic youth organization culture.

6. Making training - skills training that supports and is relevant to the youth work program in the village

7. Generating public participation in building youth evenly

8. Strengthening youth organization coordination and synergy of related resources including village stakeholders

9. Get involved in assessing every potential to be developed in the village as a form of concern for young people in developing resources in the village.

10. Full support for programs carried out by the village government by engaging youth and communities in the village.

11. Providing adequate youth empowerment infrastructure

12. Creating a system of rewards for young people who excel

13. Evaluate where the advantages and disadvantages of the role of youth are lived in the community.

\section{E. CONCLUSION AND SUGGESTIONS}

The conclusions of this study indicate that Islamic leadership training has a significant influence of $83 \%$ from the previous $67 \%$ of the millennial character to optimize the role in the community of 28 respondents obtained during the training so that thanks to the impact training program the youth felt enthusiastic during the training. I hope, the youth will return to holding Islamic leadership training as a bastion of today's millennial character and bearing in mind that this training is very beneficial for millennial to be aware of their much-needed role in society, especially their contribution to their villages. Therefore the community hopes that this training will be more caring and sensitive for their village to be able to play an active role in community activities by involving all Village Stakeholders so that they can fully support the Islamic leadership training program so that they are able to be better prepared and able give their best ideas to the village.

\section{REFERENCES}

Anggi Septia Nugroho. (2014). Management of Education Marketing in Improving the Quality of Islamic Education in Muhammadiyah 2 High School Yogyakarta. Thesis of UIN Sunan Kalijaga.

Muslim, Al-Imam. (2007). Terjemah Hadis Shahih Muslim. Jakarta: Klang Book Centre. 
8| IJECA (International Journal of Education and Curriculum Application)

Vol. 2, No.1, April 2019, 1-8

Beebe, James. (1995). Basic Concepts and Techniques of Rapid Appraisal. Human Organization, $54(1), 42-51$

Bukhari, Imam. (1987). Al-Shahih al-Bukhari. Beirut: Dar Ibnu Katsir.

Creswell, J.W. (1994). Research Design: Qualitative and Quantitative Approaches. SAGE Publications, Inc. Thousand Oaks.

Fleishman, E.A. \& Hunt, J.G. (1973). Current Development in Study of Leadership, Carbondale: Southern Illinois University Press.

Kementerian Agama RI. (2010). Al-Qur'an dan Terjemahannya. Bandung: Sygma Grafika.

Maimunah. (2017). Leadership in the Islamic Perspective and Conceptual Basis. Jurnal Al-Afkar, $5(1), 63-82$

Milles, M.B. \& Huberman, M.A. (1984). Qualitative Data Analysis. London: Sage Publication.

Rivai, Veithzal. (2004). Kepemimpinan dan Perilaku Organisasi. Jakarta: PT Raja Grafindo Persada.

Soekanto, Soerjono \& Sulistyowati, Budi. (2015). Sosiologi Suatu Pengantar. Jakarta: Rajawali Pers.

Sugiono. (2016). Metode penelitian kombinasi (Mixed Methods). Bandung: Alfabeta.

Valeeva, R.A. \& Rybakova, L.A. (2014). The Role of Youth Organization in the Development of Higher Educational Institutions Students' Humanistic Value Orientations. Procedia - Social and Behavioral Sciences, 141, 817-821.

Widianto, Aloysius Bram. (2010). Pemuda dalam Perubahan Sosial. Jurnal Historia Vitae, 24(2), 13-23 